\title{
Knowledge, attitudes and practices towards HIV/ AIDS among Iranian prisoners in Mazandaran province in the south-coast area of the Caspian Sea
}

\author{
M.R. Majdi, ${ }^{7}$ H. Khani, ${ }^{2}$ E. Azadmarzabadi, ${ }^{3}$ A. Montazeri, ${ }^{4}$ E. Hallajian, ${ }^{5}$ F. Babamahmodi ${ }^{6}$ and M.H. Kariminasab ${ }^{6}$
}

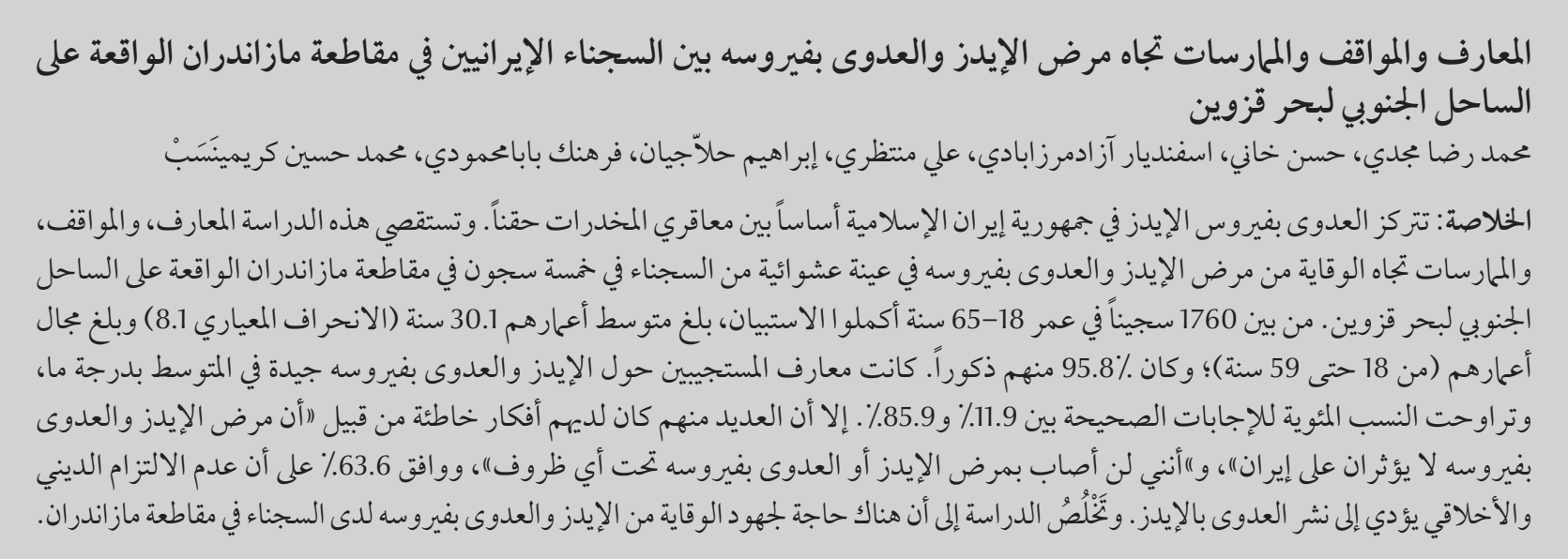

ABSTRACT HIV infection in the Islamic Republic of Iran is concentrated primarily among intravenous drug users. This study investigated the knowledge, attitudes and practices towards HIV/AIDS prevention of a random sample of prisoners in 5 prisons in Mazandaran province. Of 1760 individuals aged 18-65 years old completing the questionnaire, the mean age was 30.1 (SD 8.1) years (range 18 to 59 years); 95.8\% were male. Respondents had an average to fairly good knowledge about HIV/AIDS, with the percentages answering correctly ranging from $11.9 \%$ to $85.9 \%$. However many had the misconception that "HIV/AIDS does not influence Iran" and "I will not be infected with HIV/AIDS under any conditions" and 63.6\% agreed that lack of religious and moral commitment could spread AIDS infection. HIV/AIDS prevention efforts are needed for prisoners in Mazandaran province.

Connaissances, attitudes et pratiques concernant le $\mathrm{VIH} /$ sida chez les prisonniers iraniens de la province de Mazandaran sur la côte sud de la mer Caspienne

RÉSUMÉ L'infection à VIH en République islamique d'Iran est principalement concentrée chez les usagers de drogues injectables. La présente étude a évalué les connaissances, attitudes et pratiques concernant la prévention du VIH/sida chez des prisonniers sélectionnés aléatoirement dans cinq établissements pénitentiaires de la province de Mazandaran. Au total, 1760 personnes, âgées de 18 à 65 ans, ont rempli le questionnaire. L'âge moyen était 30,1 ans (E.T. 8,1) (extrêmes 18-59 ans) ; 95,8 \% étaient de sexe masculin. Les répondants possédaient un niveau de connaissances moyen à satisfaisant concernant le $\mathrm{VIH} /$ sida. Les pourcentages de réponses correctes allaient de 11,9 \% à 85,9 \%. Toutefois, ils étaient nombreux à avoir des conceptions erronées sur le sujet, par exemple en pensant que «le VIH/sida n'avait pas d'impact sur l'Iran» et " qu'ils ne seraient jamais infectés par le VIH/sida ». De plus, $63,6 \%$ étaient d'accord pour affirmer qu'un engagement moral et religieux défaillant pouvait contribuer à propagerl'infection à VIH. Des mesures de prévention contre le VIH/sida sont nécessaires pour les prisonniers dans la province de Mazandaran.

'Mashhad University of Medical Sciences, Mashhad, Islamic Republic of Iran.

${ }^{2}$ Iranian Applied Research Centre for Public Health and Sustainable Development, North Khorasan University of Medical Sciences, Bojnurd, Islamic Republic of Iran (Correspondence to H. Khani: dr.h.khani@gmail.com).

${ }^{3}$ Behavioural Sciences Research Centre, Baqhyatallah University of Medical Sciences, Tehran, Islamic Republic of Iran.

${ }^{4}$ Iranian Institute for Health Sciences Research, Iranian Academic Centre for Education, Culture and Research, Tehran, Islamic Republic of Iran.

Islamic Azad University, Ghaemshahr Branch, Islamic Republic of Iran.

${ }^{6}$ Department of Orthopaedic Surgery, Mazandaran University of Medical Sciences, Sari, Islamic Republic of Iran.

Received: 21/02/10; accepted: 26/04/10 


\section{Introduction}

Acquired immunodeficiency syndrome (AIDS) caused by the human immunodeficiency virus (HIV) has profoundly changed medical practice, contemporary society and public health initiatives worldwide [1]. Moreover, with no treatment or cure in sight, the disease continues to spread at an alarming rate [2]. Globally it has been estimated that 33 million people are living with HIV and 2 million people died of AIDS-related illnesses in 2007 [3].

An official report by the Iranian Ministry of Health in 2009 indicated that there were $20130 \mathrm{HIV}$-positive individuals and 2097 AIDS cases in the country [4]. Among the individuals with HIV/AIDS, 69.8\% acquired the disease through intravenous drug use, $8.5 \%$ through sexual infection, $1.2 \%$ through blood transfusion, $0.6 \%$ as newborns from infected mothers and $19.9 \%$ from unknown causes. These numbers, however, are considered inaccurate due to the inadequacy of the registration system and because people with sexually transmitted diseases do not generally attend health centres. According to the information provided by the Iranian Ministry of Health, HIV/ AIDS is considered to be in its beginning phases.

Based on HIV/AIDS distribution models in human society, many epidemiologists believe that prevention of high-risk behaviours, including unsafe sexual activities and intravenous drug use, is critical for the reduction of AIDS-associated morbidity and mortality [5-7]. Prevention of high-risk behaviours in human society is related to increased knowledge and improved attitudes and beliefs concerning HIV/ AIDS [8-11]. The World Health Organization (WHO) has advocated an important role for education in spreading knowledge about HIV/AIDS transmission [12].
The development and implementation of HIV/AIDS prevention programmes has been relatively slow in prisons in the area around the southern coast of the Caspian Sea [13]. As in other countries [14-16], inmates may fear that, by expressing an open interest in learning about HIV/AIDS prevention strategies or requesting testing, they are openly admitting to engaging in homosexual activities or using drugs, which may cause others to view them in a negative light [17-19]. This paper reports on data derived from an investigation of the knowledge, attitudes and practices towards HIV/AIDS prevention among prisoners in Mazandaran province, Islamic Republic of Iran.

\section{Methods}

\section{Study design}

This was a cross-sectional descriptive study investigating the state of knowledge, attitudes and practices towards HIV/AIDS of Iranian prisoners living in prisons along the southern coast of the Caspian Sea between 2006 and 2008. The study protocol was approved by the ethics review committees of 5 institutions to which the authors are affiliated, and all participants gave written informed consent.

\section{Participants}

In view of the lack of previous statistical data on acceptable knowledge about AIDS among prisoners in Mazandaran province, we estimated that 400 subjects were required for each cluster to achieve a suitable sample size. A random sample of 2000 individuals aged between 18 and 65 years old who were incarcerated in 5 prisons in 5 cities in Mazandaran province (Amole, Babol, Behshahr, Ghaemshahr and Sari) were selected and invited to participate in this study. Every prisoner had the same probability of being sampled.

\section{Data collection}

Data for the main study was collected by a group of trained interviewers in face-to-face interviews. Prisoners who agreed to participate were given a 4-page self-administered questionnaire. Those who had difficulty in reading the questionnaire were provided with assistance.

\section{Questionnaire}

The questionnaire used in this survey was adopted from the knowledge, attitudes, beliefs and practices survey of the WHO HIV/AIDS programme [20] and the previous literature [2,21-23]. However, some items related to sexual habits were modified in to suit Iranian culture and norms. The questionnaire consisted of 44 questions in 5 broad sections:

- Sociodemographic information: age, sex, marital status, educational level, employment status, self-reported economic status, number of family members, and type of criminal behaviour ( 8 items).

- Questions about HIV/AIDS-related knowledge covering 4 main topics: general information, diagnosis, risk of HIV/AIDS transmission and treatment (25 items).

- Statements about the individual's attitudes towards HIV/AIDS, covering social and cultural issues (6 items).

- Questions about the individual's participation in practices concerning HIV/AIDS prevention (2 items).

- Questions about the individual's source of information on HIV/ AIDS and information needs (3 items).

The response categories for the section on knowledge were in a yes/ no/I don't know format, and items on attitudes were assessed using a 5-point Likert scale ranging from strongly agree to strongly disagree. 


\begin{tabular}{|c|c|c|}
\hline Characteristic & No. & $\%$ \\
\hline \multicolumn{3}{|l|}{ Age (years) } \\
\hline$\leq 24$ & 442 & 25.1 \\
\hline $25-34$ & 846 & 48.1 \\
\hline $35-44$ & 360 & 20.5 \\
\hline$\geq 45$ & 112 & 6.4 \\
\hline \multicolumn{3}{|l|}{ Sex } \\
\hline Male & 1686 & 95.8 \\
\hline Female & 74 & 4.2 \\
\hline \multicolumn{3}{|l|}{ Marital status } \\
\hline Single & 640 & 36.4 \\
\hline Married & 1054 & 59.9 \\
\hline Widowed & 66 & 3.8 \\
\hline \multicolumn{3}{|l|}{ Education level } \\
\hline Illiterate & 582 & 33.1 \\
\hline Primary & 392 & 22.3 \\
\hline Secondary & 632 & 35.9 \\
\hline Higher education & 154 & 8.8 \\
\hline \multicolumn{3}{|l|}{ Employment status ${ }^{a}$} \\
\hline Employed & 846 & 48.1 \\
\hline Housewife & 74 & 4.2 \\
\hline Student & 60 & 3.4 \\
\hline Unemployed & 780 & 44.3 \\
\hline \multicolumn{3}{|c|}{ Family's total annual income level ${ }^{a}$} \\
\hline Low & 688 & 39.1 \\
\hline Average & 1002 & 56.9 \\
\hline High & 70 & 4.0 \\
\hline \multicolumn{3}{|c|}{ Household size (no. of people) ${ }^{b}$} \\
\hline $1-3$ & 534 & 30.3 \\
\hline $4-5$ & 766 & 43.5 \\
\hline$\geq 6$ & 460 & 26.1 \\
\hline \multicolumn{3}{|l|}{ Reason for imprisonment } \\
\hline Drug abuse/addiction & 594 & 33.8 \\
\hline Theft/ethical & 630 & 35.8 \\
\hline Financial/penal & 536 & 30.5 \\
\hline
\end{tabular}

${ }^{a}$ Participants' self-reported estimates; ${ }^{b}$ Before imprisonment.

Panels of 4 health professionals from 4 institutions (Baqhyatallah University of Medical Sciences, Iranian Institute for Health Sciences Research, Mazandaran University of Medical Sciences and Islamic Azad University) examined and validated the questionnaire. Following approval, the questionnaire was pre-tested on a sample of 75 participants ( 15 individuals per prison). Alpha coefficients for reliability and internal consistency of the questions were 0.82 and 0.68 for knowledge and attitudes respectively.

\section{Statistical analysis}

Descriptive statistics - percentages, mean and standard deviation (SD) were used to report frequencies. Chisquared analysis was used to test for the associations of knowledge, attitudes and practices with age, sex, educational level, marital status, employment status, total family income level, number of those living at home and type of criminal behaviour.

\section{Results}

\section{Respondents' characteristics}

Of the 2000 eligible participants, 1760 (88.0\%) completed the questionnaire. The characteristics of the respondents are shown in Table 1 . The mean age of the respondents was 30.1 (SD 8.1) years (range 18 to 59 years); $95.8 \%$ were male, $59.9 \%$ were married and $91.2 \%$ had received secondary education or lower. Most respondents (96.0\%) identified themselves as having low or intermediate income and $44.3 \%$ were unemployed before imprisonment. One-third (33.8\%) had been imprisoned for drug abuse/addiction.

\section{Respondents' knowledge}

On most items, respondents had an average to fairly good knowledge about HIV/AIDS, with the percentages answering correctly ranging from $11.9 \%$ to $85.9 \%$ (Table 2). The great majority knew that AIDS was caused by a virus (81.6\%), that HIV/AIDS can be transmitted by sharing a razor blade with an infected person (85.8\%) or using a needle previously used by an infected person $(85.2 \%)$ and that HIV/AIDS can be transmitted from an infected person to his or her partner during sexual intercourse (85.9\%). However, over $30 \%$ of respondents thought that AIDS was not a contagious disease (34.8\%), that urine, $\mathrm{X}$-ray, blood and biochemistry tests were used to check for the HIV virus in the blood (56.9\%), that HIV virus can be transmitted through the bite of a mosquito (49.2\%) or by using an infected person's belongings, such as clothes, combs, underwear and towels (35.9\%).

On 19 of 25 knowledge items, HIV/AIDS related knowledge was significantly associated with age group; the 


\begin{tabular}{|c|c|c|c|c|c|c|}
\hline \multirow[t]{2}{*}{ Knowledge item } & \multicolumn{2}{|c|}{ Correct } & \multicolumn{2}{|c|}{ Incorrect } & \multicolumn{2}{|c|}{ Don't know } \\
\hline & No. & $\%$ & No. & $\%$ & No. & $\%$ \\
\hline \multicolumn{7}{|l|}{ General knowledge } \\
\hline A virus causes AIDS & 1436 & 81.6 & 166 & 9.4 & 158 & 9.0 \\
\hline AIDS is an infectious disease & 1006 & 57.2 & 612 & 34.8 & 142 & 8.1 \\
\hline AIDS is a hereditary disease & 1218 & 69.2 & 362 & 20.6 & 180 & 10.2 \\
\hline $\begin{array}{l}\text { AIDS is mostly seen in developing or undeveloped } \\
\text { countries, unable to afford to care for infected people }\end{array}$ & 1132 & 64.3 & 230 & 13.1 & 398 & 22.6 \\
\hline $\begin{array}{l}\text { AIDS is not a serious disease. It is a simple disease like } \\
\text { the common cold }\end{array}$ & 1422 & 80.8 & 226 & 12.8 & 112 & 6.4 \\
\hline $\begin{array}{l}\text { The appearance of HIV carriers does not differ from that } \\
\text { of the normal population }\end{array}$ & 1034 & 58.8 & 546 & 31.0 & 180 & 10.2 \\
\hline $\begin{array}{l}\text { Resistance to other diseases in an individual with AIDS is } \\
\text { rather low }\end{array}$ & 1336 & 75.9 & 232 & 13.2 & 192 & 10.9 \\
\hline \multicolumn{7}{|l|}{ Diagnosis } \\
\hline $\begin{array}{l}\text { A person infected with HIV is usually diagnosed with } \\
\text { symptoms of the disease }\end{array}$ & 1040 & 59.1 & 504 & 28.6 & 216 & 12.3 \\
\hline $\begin{array}{l}\text { An ELISA test is used to check for the HIV virus in the } \\
\text { blood }\end{array}$ & 848 & 48.2 & 184 & 10.5 & 728 & 41.4 \\
\hline $\begin{array}{l}\text { Urine, X-ray, total blood count and biochemistry } \\
\text { analyses are used to check for the HIV virus in the blood }\end{array}$ & 210 & 11.9 & 1002 & 56.9 & 548 & 31.1 \\
\hline \multicolumn{7}{|l|}{ Risk of transmission } \\
\hline $\begin{array}{l}\text { Sharing public toilets and swimming pools with an } \\
\text { infected person }\end{array}$ & 946 & 53.8 & 542 & 30.8 & 272 & 15.5 \\
\hline $\begin{array}{l}\text { Using an infected person's belongings such as clothes, } \\
\text { comb, underwear and towel }\end{array}$ & 936 & 53.2 & 632 & 35.9 & 192 & 10.9 \\
\hline Sharing a razor blade with an infected person & 1510 & 85.8 & 114 & 6.5 & 136 & 7.7 \\
\hline $\begin{array}{l}\text { Sharing an injection needle or surgical instrument } \\
\text { previously used by an infected person }\end{array}$ & 1500 & 85.2 & 140 & 8.0 & 120 & 6.8 \\
\hline Sharing the food utensils of an infected person & 872 & 49.5 & 620 & 35.2 & 268 & 15.2 \\
\hline $\begin{array}{l}\text { Touching an infected person, such as hugging, holding } \\
\text { and shaking hands }\end{array}$ & 1350 & 76.7 & 264 & 15.0 & 146 & 8.3 \\
\hline From a mosquito bite & 586 & 33.3 & 866 & 49.2 & 308 & 17.5 \\
\hline $\begin{array}{l}\text { Donating blood, organs or tissue of an infected person } \\
\text { to another person }\end{array}$ & 1432 & 81.4 & 172 & 9.8 & 156 & 8.9 \\
\hline From an infected pregnant woman to her unborn baby & 1410 & 80.1 & 168 & 9.5 & 182 & 10.3 \\
\hline $\begin{array}{l}\text { From an infected person to his/her partner during sexual } \\
\text { intercourse }\end{array}$ & 1512 & 85.9 & 130 & 7.4 & 118 & 6.7 \\
\hline From to an infected person who coughs or spits & 930 & 52.8 & 570 & 32.4 & 260 & 14.8 \\
\hline $\begin{array}{l}\text { From the urine, tears, mucus or nasal fluid of an infected } \\
\text { person }\end{array}$ & 748 & 42.5 & 674 & 38.3 & 338 & 19.2 \\
\hline From the breast milk of an infected person & 1154 & 65.6 & 316 & 18.0 & 290 & 16.5 \\
\hline \multicolumn{7}{|l|}{ Treatment } \\
\hline There is an active treatment for AIDS & 1134 & 64.4 & 362 & 20.6 & 264 & 15.0 \\
\hline There is a vaccine for AIDS & 1084 & 61.6 & 462 & 26.3 & 214 & 12.2 \\
\hline
\end{tabular}

percentage of respondents aged 25-34 years with correct answers on all items was higher than that of respondents aged $\geq 45$ years. On 9 items, the percentage of males responding correctly was significantly higher than that of females. On 24 items, respondents with a higher level of education were significantly more knowledgeable than those with a lower level of education. There were also significant differences relative to other demographic characteristics on most 


\begin{tabular}{|c|c|c|c|c|c|c|c|c|c|c|}
\hline \multirow[t]{2}{*}{ Attitudes item } & \multicolumn{2}{|c|}{ Strongly agree } & \multicolumn{2}{|c|}{ Agree } & \multicolumn{2}{|c|}{$\begin{array}{l}\text { Neither agree } \\
\text { nor disagree }\end{array}$} & \multicolumn{2}{|c|}{ Disagree } & \multicolumn{2}{|c|}{$\begin{array}{l}\text { Strongly } \\
\text { disagree }\end{array}$} \\
\hline & No. & $\%$ & No. & $\%$ & No. & $\%$ & No. & $\%$ & No. & $\%$ \\
\hline $\begin{array}{l}\text { Lack of religious and moral } \\
\text { commitment could spread } \\
\text { AIDS infection }\end{array}$ & 670 & 38.1 & 448 & 25.5 & 304 & 17.3 & 244 & 13.9 & 94 & 5.3 \\
\hline AIDS is a punishment from God & 236 & 13.4 & 162 & 9.2 & 390 & 22.2 & 536 & 30.5 & 436 & 24.8 \\
\hline AIDS does not influence Iran & 222 & 12.6 & 380 & 21.6 & 514 & 29.2 & 376 & 21.4 & 268 & 15.2 \\
\hline $\begin{array}{l}\text { Married couples do not contract } \\
\text { AIDS }\end{array}$ & 280 & 15.9 & 276 & 15.7 & 384 & 21.8 & 524 & 29.8 & 296 & 16.8 \\
\hline I will not be infected with AIDS & 322 & 18.3 & 388 & 22.0 & 406 & 23.1 & 390 & 22.2 & 254 & 14.4 \\
\hline $\begin{array}{l}\text { You cannot be infected with HIV/ } \\
\text { AIDS if you engage in sport and } \\
\text { are well-nourished }\end{array}$ & 226 & 12.8 & 124 & 7.0 & 318 & 18.1 & 638 & 36.3 & 454 & 25.8 \\
\hline
\end{tabular}

knowledge items (data not shown, but available from the corresponding author).

\section{Respondents' attitudes}

The data concerning respondents' attitudes are listed in Table 3. The majority of respondents had negative attitudes toward HIV/AIDS. There were also a number of misconceptions: $34.2 \%$ of the respondents agreed (i.e. answered agree/strongly agree) with the statement
"HIV/AIDS does not influence Iran", 40.3\% agreed that "I will not be infected with HIV/AIDS under any condition" and $63.6 \%$ agreed that "lack of religious and moral commitments could cause HIV/AIDS infection". Overall, there were significant differences for almost all attitude items according to the demographic characteristics of the respondents (data not shown, but available from the corresponding author).

\begin{tabular}{lcc}
\hline $\begin{array}{l}\text { Table } 4 \text { Respondents' source of information about HIV/AIDS and their } \\
\text { informational needs }(\boldsymbol{n}=\mathbf{1 7 6 0})\end{array}$ & No. \\
\hline Item & 244 & 13.9 \\
Level of information about HIV/AIDS ${ }^{\boldsymbol{a}}$ & 30.6 \\
$\quad$ Excellent & 538 & 36.3 \\
Good & 638 & 12.2 \\
Average & 214 & 7.2 \\
Low & 126 & \\
Very low & & 50.4 \\
Source of information about HIV/AID & 958 & 26.6 \\
$\quad$ Television & 468 & 14.9 \\
Newspapers & 262 & 10.3 \\
Friends & 182 & 6.4 \\
Books & 112 & 4.7 \\
Radio & 82 & \\
Family & & 41.1 \\
Information needs & & 35.9 \\
Transmission modes & 722 & 32.6 \\
General information & 632 & 3.4 \\
Prevention & 574 & \\
Other & 60 & \\
\hline
\end{tabular}

aParticipants'self-report.

\section{Respondents' practices}

Of the respondents, $73.4 \%(n=1292)$ reported that their sexual practices were safe, and based on religious and moral commitments to prevent HIV/AIDS. In addition, $92.7 \%(n=1632)$ would agree to undergo a blood test to check for the HIV virus. Overall, there were significant demographic differences in responses to both practices items, except for marital status and number of family members (data not shown, but available from the corresponding author).

\section{Respondents' source of information and their informational needs}

As shown in Table 4, the majority of the respondents indicated that mass media (radio, television, and newspapers) were their major source of their information about HIV/AIDS (83.4\%). Many, however, indicated that they needed more general information about HIV/ AIDS (35.9\%), as well as information on prevention $(32.6 \%)$ and modes of transmission (41.1\%).

\section{Discussion}

The prevention of HIV infection remains an important task for public health professionals. Understanding the dynamics of HIV infection within a 
country, how it changes over time and who is currently at greatest risk is essential for guiding decisions about effective prevention programmes [24]. HIV infection in the Islamic Republic of Iran is concentrated primarily among intravenous drug users, suggesting an urgent need for prevention approaches targeted to this group [22]. Prisons and prison inmates are important targets for HIV/AIDS prevention interventions. Inmates often have a history of highrisk behaviour that place them at risk of contracting HIV/AIDS, and rates of HIV/AIDS tend to be much higher in this population. The present study therefore investigated the knowledge, attitudes and practices towards HIV/ AIDS prevention among a sample of Iranian prisoners.

Ourfindingsindicated that prisoners in Mazandaran province demonstrated average to fairly good knowledge about HIV/AIDS. However, misconceptions were present. For example, $34.8 \%$ of respondents believed that HIV/AIDS was not an infectious disease, $49.2 \%$ that mosquitoes were a vector of the virus and $31.0 \%$ that HIV carriers differed in appearance from non-infected individuals. In addition, the respondents showed limited knowledge about how HIV and AIDS can be transmitted. For example, only $52.8 \%$ said that AIDS could not be transmitted through coughing or spitting by an infected person. Overall, those who had higher levels of education and young adults (aged 25-34 years) were more knowledgeable about HIV/AIDS. Similar findings have been reported in other countries $[9,10]$.

A study among prisoners in Lagos, Nigeria, showed that almost all of them had heard of AIDS, although only a few had seen or known a person with AIDS [25]. Although many knew the correct modes of HIV transmission, many indulged in high-risk behaviours. The study concluded that well designed information, education and communication programmes on HIV/AIDS were urgently needed for prisoners in low-income countries to work towards reducing the risk of HIV/AIDS transmission among prison inmates [25]. It has been argued that HIV/AIDS education interventions for male prisoners reduce the rate of high-risk behaviours [26]. Since the level of general education among our Iranian prisoners was only average, health education interventions may help to improve safe practices, especially as many of the respondents had been involved in high-risk behaviours (over a quarter had unsafe sex practices and one-third were imprisoned for drug abuse/addiction).

Most respondents had erroneous attitudes. For example many had the misconception that "HIV/AIDS does not influence Iran" and "I will not be infected with HIV/AIDS under any conditions". Several studies have shown that people with good knowledge about HIV/ AIDS become more tolerant of people with HIV/AIDS [27]. Also $63.6 \%$ of the respondent agreed that "lack of religious and moral commitments could cause HIV/AIDS infection”. Further investigation of the role of religion in HIV/ AIDS prevention is needed, especially in countries such as Islamic Republic of Iran where religion has an important role in everyday life [22].

The majority of respondents (83.4\%) indicated that their main source of information about HIV/ AIDS was the mass media, especially television, showing that these methods have succeeded in raising AIDS awareness in Islamic Republic of Iran. In contrast, only $4.7 \%$ said that their main source of information was their family. A recent study in the Islamic Republic of Iran indicated that many people could not correctly identify the main message of anti-HIV/AIDS campaigns [28].

Our findings indicate the urgent need for HIV/AIDS prevention efforts for prisoners throughout Mazandaran province to increase their knowledge of HIV/AIDS, and to improve their attitudes and practices concerning this disease.

\section{Acknowledgements}

The authors thank the study sites and instructors for their valuable contribution. They also thank those who helped with this study, especially the researchers who evaluated the questionnaire and those who carried out the interviews.

\section{References}

1. Schreirman T, Friedland G. Human immunodeficiency virus infection prevention: strategies for clinicians. Clinical Infectious Diseases, 2003, 36:1171-1176.

2. Unal A. AIDS knowledge and attitudes in Turkish population: an epidemiological study. BMC Public Health, 2005, 5:95.

3. Report on the global HIV/AIDS epidemic. Geneva, Joint United Nations Programme on HIV/AIDS and World Health Organization, 2008.

4. HIV/AIDS statistics. Tehran, Ministry of Health, 2009 [in Farsi].

5. Seekoe E. Reproductive health needs and the reproductive health behavior of the youth in Mangaung in the Free State province: a feasibility study. Curationis, 2005, 28:20-30.
6. MillerJE, Guarnaccia PJ, Fasina A. AIDS knowledge among Latinos: the roles of language, culture, and socioeconomic status. Journal of Immigrant Health, 2002, 4:63-72.

7. Rotily $\mathrm{M}$ et al. Connaissances et attitudes du personnel de surveillance penitentiaire face au VIH et/ou SIDA: une enquete europeenne. [Knowledge and attitudes of prison staff towards HIV/AIDS: a European study.] Santé publique, 2001, 13:325-338.

8. Helleringer S, Kohler HP. Social networks, perceptions of risk, and changing attitudes towards HIV/AIDS: new evidence from a longitudinal study using fixed-effects analysis. Population Studies, 2005, 59:265-282. 
9. Zhao $\mathrm{M}$ et al. Risk behaviors and HIV/AIDS prevention education among IDUs in drug treatment in Shanghai. Journal of Urban Health, 2005, 82(Suppl. 4):84-91.

10. Amirkhanian YA et al. A randomized social network HIV prevention trial with young men who have sex with men in Russia and Bulgaria. AIDS, 2005, 19:1897-1905.

11. Al-Mazrou YY, Abouzeid MS, Al-Jeffri MH. Impact of health education on knowledge and attitudes of Saudi paramedical students toward HIV/AIDS. Saudi Medical Journal, 2005, 26:1788-1795.

12. Rashed A et al. Knowledge, attitudes, beliefs and practices of the population in Kuwait about AIDS: a pilot study. Eastern Mediterranean Health Journal, 1995, 1:235-240.

13. Statistical yearbook. Mazandaran, Islamic Republic of Iran, Management and Planning Organization of Mazandaran Province, 2006 [in Farsi].

14. Polonsky $S$ et al. HIV prevention in prisons and jails: obstacles and opportunities. Public Health Reports, 1994, 109:615-625.

15. Grinstead OA et al. Reducing postrelease HIV risk among male prison inmates. Criminal Justice and Behavior, 1999, 26:453-459.

16. Heckman TG et al. HIV risk differences between AfricanAmerican and White men who have sex with men. Journal of the National Medical Association, 1999, 91:92-100.

17. Arriola KRJ et al. Development and implementation of the cross-site evaluation of the CDC/HRSA Corrections Demonstration Project. AIDS Education and Prevention, 2002, 14(Suppl. A):107-118

18. L.Braithwaite R and J.Arriola K.R. Male prisoners and HIV prevention. a call for action ignored. American Journal of Public Health, 2003, 93:759-763.
19. McCusker J et al. Demographic characteristics, risk behaviors, and HIV seroprevalence among intravenous drug users by site of contact: results from a community-wide HIV surveillance project. American Journal of Public Health, 1990, 80:1062-1067.

20. Interview schedule on knowledge, attitudes, beliefs, and practices on AIDS/KABP survey. Geneva, World Health Organization, 1988.

21. Tavossi A et al. Knowledge and attitude toward HIV/AIDS among Iranian students. BMC Public Health, 2004, 4:17.

22. Montazeri A. AIDS knowledge and attitudes in Iran: results from a population-based survey in Tehran. Patient Education and Counseling, 2005, 57:199-203.

23. Nakhaee FH. Prisoners' knowledge of HIV/AIDS and its prevention in Kerman, Islamic Republic of Iran. Eastern Mediterranean Health Journal, 2002, 8:725-731.

24. Pisani E et al. Back to basics in HIV prevention: focus on exposure. British Medical Journal, 2003, 326:1384-1387.

25. Odujinrin MT, Adebajo SB. Social characteristics, HIV/AIDS knowledge, preventive practices and risk factors elicitation among prisoners in Lagos, Nigeria. West African Journal ofMedicine, 2001, 20:191-198.

26. Ronald LB, Kimberly RJA. Male prisoners and HIV prevention: a call for action ignored. American Journal of Public Health, 2003, 93:759-763.

27. Maswanya E et al. Knowledge and attitudes toward AIDS among Female college students in Nagasaki. Health Education Research, 2000, 15:5-11.

28. Montazeri A et al. World AIDS Day campaign in Iran: a population-based study. Iranian Journal of Public Health, 2009, 38:1-3. 